\title{
Modern diagnostics and treatment of combined congenital cardiovascular system and gastrointestinal tract malformations
}

\author{
T. Ye. Shumna ${ }^{1}$, M. O. Makarova ${ }^{1}$, O. V. Panchenko² \\ ${ }^{1}$ Zaporizhzhia State Medical University, Ukraine, ${ }^{2}$ Municipal Institution “City Multifield Children's Hospital No. 5”, Zaporizhzhia, Ukraine
}

Purpose - to share the experience of qualified medical care providing to newborn children born with combined abnormal development.

Materials and methods. Diagnostics, treatment of a newborn child and further monitoring was performed according to the protocols of the Ministry of Health of Ukraine for the diagnosis and treatment of cardiovascular system and gastrointestinal tract diseases in children.

Results. The article describes a case of girl clinical observation, born with combined cardiovascular and gastrointestinal tract anomalies. The main data of anamnesis, objective, laboratory and instrumental examination, the results of child with combined congenital malformations of cardiovascular system and gastrointestinal tract treatment are presented: double outlet right ventricle, atrial septal defect, ventricular septal defect and esophageal atresia, tracheoesophageal fistula, duodenal atresia.

Conclusions. All pregnant women should undergo ultrasound and screening genetic examinations to exclude or diagnose congenital malformations in the fetus. The success of therapy and surgical correction, the quality of child life depend on timely diagnosis, continuity and good teamwork of neonatologists, pediatric surgeons, cardiologists, pediatricians, diagnosticians.

\section{Сучасна діагностика та Аікування поєднаних вроджених вад розвитку серцево-судинної системи та шлунково-кишкового тракту}

\author{
Т. Є. Шумна, М. О. Макарова, О. В. Панченко
}

Мета роботи - передати досвід надання кваліфікованої медичної допомоги новонародженим дітям, які народились із поєднаними аномаліями розвитку.

Матеріали та методи. Діагностику, лікування новонародженої дитини та диспансерне спостереження здійснили згідно з протоколами МОЗ України з діагностики та лікування захворювань серцево-судинної системи та шлунково-кишкового тракту в дітей.

Результати. Описаний випадок клінічного спостереження дівчинки, котра народилась з аномаліями серцево-судинної системи та шлунково-кишкового тракту. Наведені основні дані анамнезу, об'єктивного, лабораторного та інструментального обстеження, результати лікування дитини з подвійним відходженням магістральних судин від правого шлуночка, десректом міжшлуночкової та міжпередсердної перегородок та атрезією стравоходу з нижньою трахеостравохідною норицею, атрезією дванадцятипалої кишки.

Висновки. Усі вагітні жінки повинні проходити ультразвукові та скринінгові генетичні обстеження для виключення або діагностики вроджених вад розвитку у плода. Успішність терапії та хірургічної корекції, якість життя дитини залежать від своєчасної діагностики, посередництва (наступництва) та злагодженої командної роботи неонатологів, дитячих хірургів, кардіологів, педіатрів, діагностів.

\section{Современная диагностика и лечение сочетанных врожденных пороков развития сердечно-сосудистой системы и желудочно-кишечного тракта}

\section{Т. Е. Шумная, М. О. Макарова, А. В. Панченко}

Цель работы - передать опыт оказания квалифицированной медицинской помощи новорожденным, родившимся с сочетанными аномалиями развития.

Материалы и методы. Диагностика, лечение новорожденного ребенка и диспансерное наблюдение проводилось согласно протоколам МЗ Украины по диагностике и лечению заболеваний сердечно-сосудистой системы и желудочно-кишечного тракта у детей.

Результаты. Описан случай клинического наблюдения девочки, родившейся с сочетанными аномалиями сердечно-сосудистой системы и желудочно-кишечного тракта. Представлены основные данные анамнеза, объективного, лабораторного и инструментального обследования, результаты лечения ребенка с двойным отхождением магистральных сосудов от правого желудочка, дефектом межжелудочковой и межпредсердной перегородок и атрезией пищевода с нижним трахеопищеводным свищем, атрезией двенадцатиперстной кишки.

Выводы. Все беременные женщины должны проходить ультразвуковые и скрининговые генетические обследования для исключения или диагностики врожденных пороков развития у плода. Успешность терапии и хирургической коррекции, качество жизни ребенка зависят от своевременной диагностики, преемственности и слаженной командной работы неонатологов, детских хирургов, кардиологов, педиатров, диагностов.

Key words: clinical case, congenital abnormalities, cardiovascular system, gastrointestinal tract, newborn infant.

\section{Zaporozhye} medical journal 2018; 20 (2), 285-290 DOl: 10.14739/2310-1210. 2018.2.125536

E-mail: tshumnaya72@ gmail.com

Кнючові слова: кмінічний випадок, уроджені аномалії, серцево-судинна система, шлунковокишковий тракт, новонароджена Аитина.

Запорізький медичний журнал. - 2018. T. 20, № 2(107). C. $285-290$ 


\section{Introduction}

Nowadays, despite the achievements of modern medicine, the birth of children with congenital anomalies remains one of the topical problems in paediatrics. The most common cause of children mortality after the newborns period is concomitant congenital malformations. Among them, the ratio of gastrointestinal tract vestiges makes up $13.1 \%$ [1]. Therewith, the degree of esophageal atresia incidence is 1 out of 3500 children [2]. Also, the gastrointestinal tract abnormalities all of others are decisive in clinical state of patients destabilization and require surgical treatment already in the newborn period [3].

The frequency of congenital heart disease is about $1 \%$ [4]. But according to some theoretical data, heart defects without cyanosis with pulmonary blood overflow are registered in $49 \%$ and with cyanosis with decreased pulmonary blood flow - in $19 \%$ in the structure of all congenital heart defects [5]. The rare defect of cardiovascular system development - a double-outlet of right ventricle in which both the aorta and the pulmonary artery completely or predominantly originate from the right ventricle is of great interest, it occurs in $1 \%$ of cases in humans and, in rare cases even in animals $[6,7]$. This heart defect can also be combined with other defects or be a part of combined developmental anomalies. One of such combined anomalies is, for example, the VACTERL-association, which although is formed sporadically, but its risk in subsequent delivery ranges from $1 \%$ to $50 \%$ [8].

Now, with mandatory screening ultrasound examination of the fetus in the intrauterine period, early detection of congenital anomalies has improved and now it makes possible to choose the most optimal ways to solve this problem. Thus, physicians have the experience of double transposition of the main vessels from the right ventricle diagnosis, but without combination with other developmental anomalies with the help of two-dimensional sonography of four fetuses at the 17th, 20th, 26th and 28th weeks of pregnancy [9]. After birth, timely and balanced preoperative preparation, surgical correction of congenital anomalies, monitoring in the postoperative period are important links in children developmental malformations successful treatment [10].

In general, the care and health of children born with malformations depends on the well-coordinated teamwork of neonatologists, pediatric surgeons, pediatricians, diagnosticians and, of course, parents.

\section{Purpose}

To share the experience of qualified medical care providing to newborn children born with combined developmental abnormalities.

\section{Materials and methods}

Diagnostics and treatment of a newborn child and further monitoring was performed according to the protocols of the Ministry of Health of Ukraine for the diagnosis and treatment of cardiovascular system and gastrointestinal tract diseases in children.

\section{Clinical case}

The child K., a girl, was admitted on 11.12.2014 to the Municipal Institution "City Multifield Children's Hospital No. 5" in Zaporizhzhia, with congenital malformations of the cardiovascular system and gastrointestinal tract.

Anamnesis vitae. The girl was born of the 2 nd pregnancy on 11.12.2014. Previous first pregnancy in 2012 was anembrionic. With regard to the second pregnancy, the observation was started from the 12-13th week; at the 15-16th week there was a threatened miscarriage; at the $23 \mathrm{~d}$ week multiple developmental anomalies were diagnosed; at the 37th week fetal growth retardation, malignancy, congenital malformations of the gastrointestinal tract and cardiovascular system were diagnosed. Mother was 36 years old at the moment of the child's birth, she was out of work and has been followed up because of hydrocolysis of the right kidney; child's father was 43 years old, worked as a turner; since 2010 he has been subjected to regular medical examinations by a phthisiatrician with pulmonary tuberculosis.

The infant was delivered at 37 weeks of gestation with anhydrous interval of 13 hours and 50 minutes, but the amniotic fluid was light-coloured. Weight at birth was 2030 grams, body length was $51 \mathrm{~cm}$, chest circumference was $29 \mathrm{~cm}$, head circumference was $35 \mathrm{~cm}$, Apgar score was $7 / 8$ points. On the same day the child was taken from the maternity hospital for further treatment and examination to the children's hospital by an emergency brigade.

Anamnesis morbi. The next day after birth, on 12.12.2014, in the Department of Pediatric Surgery the child was promptly operated for the gastrointestinal tract developmental disorder: "Esophageal atresia, tracheoesophageal fistula, duodenal atresia". Operative treatment included tracheoesophageal fistula ligation, bowel segment resection and esophagoesophageal, duodenoduodenostomy anastomosis end-to-end. Postoperative treatment included broad-spectrum antibiotics, antifungal drug, infusion therapy, parenteral nutrition from the first day after surgery, correction of water and electrolyte imbalance and acid-base status.

In the Department of Newborn Pathology, where the child was subsequently nursed and treated, the cardiovascular system developmental defect was specified: "Double outlet right ventricle (DORV), atrial septal defect (ASD), ventricular septal defect (VSD)".

Objectively: Temperature $-36.6{ }^{\circ} \mathrm{C}$. Heart rate $160 / \mathrm{min}$. Respiratory rate $-80 / \mathrm{min}$. Arm blood pressure 100/50, leg blood pressure - 130/80.

Severity of child's condition was caused by heart failure II A, malnutrition. Child has general weakness, pale skin, perioral and periorbital cyanosis, dyspnea. Auscultation: congestive moist rales were audible over both lung fields. Cardiac auscultation revealed tachycardia, rough systolic murmur in the 2-3-4 left intercostals spaces and the second heart sound was accentuated at the pulmonic and cardiac base areas. Percussion: heart borders are dislocated to left and right side. Hepatomegaly. Diuresis was adequate. Constipation.

Laboratory examination

Clinical blood test: RBC $-4,3 \times 10^{12} / \mathrm{L}$; Hemoglobin - $134 \mathrm{~g} / \mathrm{L} ;$ Colour index - 0,94; WBC - 10,2 × 109/L; Eosinophils - $0 \%$; Basophils $-4 \%$; Neutrophils $-42 \%$; Lymphocytes - $46 \%$; Monocytes - $8 \%$; Platelets - 


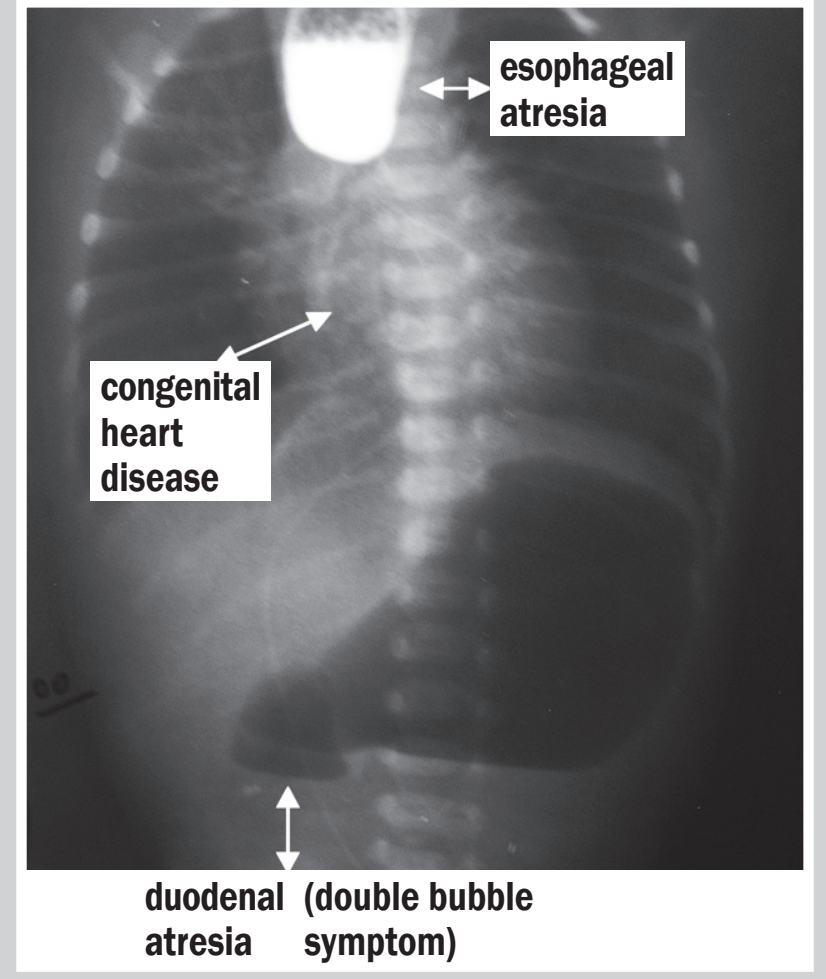

Fig. 1. X-ray "Esophageal atresia and duodenal atresia".

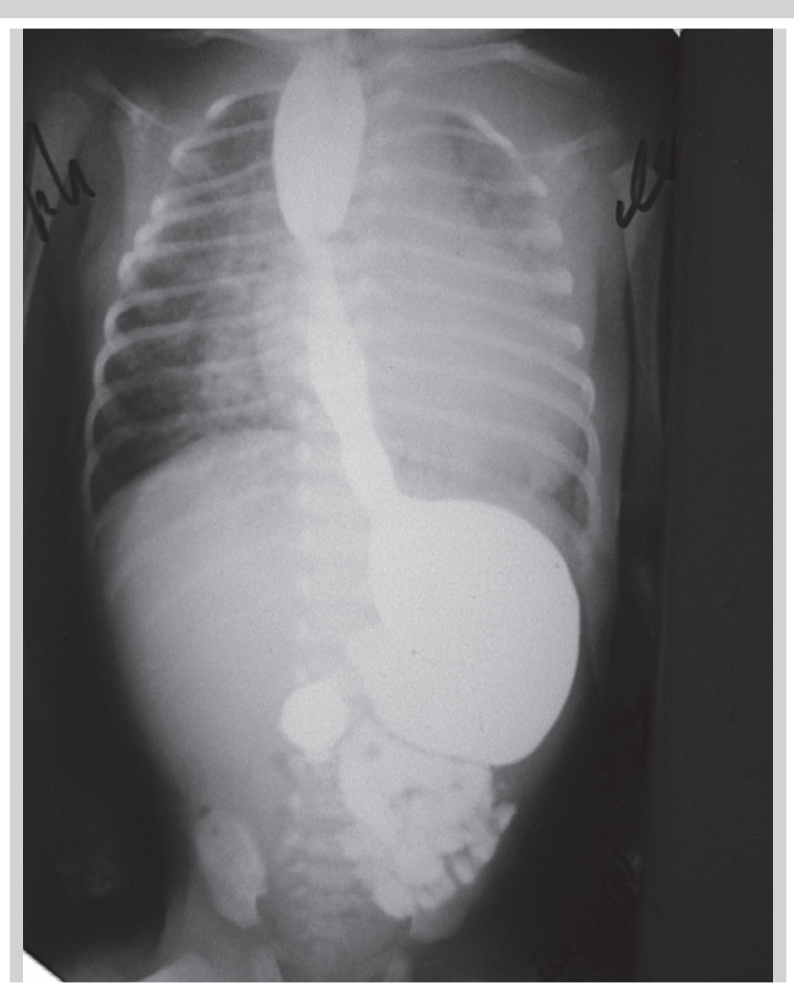

Fig. 2. X-ray after treatment of esophageal atresia and duodenal atresia.
$240 \times 10^{9} / \mathrm{L}$; Erythrocytes sedimentation rate (ESR) $6 \mathrm{~mm} /$ hour.

Biochemical blood test: Protein - $52 \mathrm{~g} / \mathrm{L}$; Bilirubin Total - $14 \mathrm{mcmol} / \mathrm{L} ;$ ALT - 1,57 mmol/L; Thymol test - 0,13 Unit; Glucose - 3,8 mmol/L; Creatinine - $56 \mathrm{mcmol} / \mathrm{L}$; BUN $-5,9 \mathrm{mmol} / \mathrm{L}$

Serum electrolytes: Calcium - 2,24 mmol/L; Potassium - 3,79 mmol/L; Phosphorus - 1,98 mmol/L; Sodium $138 \mathrm{mmol} / \mathrm{L}$.

Coagulogram, urine analysis - normal.

Instrumental examination

X-ray (Fig. 1): "Esophageal atresia and duodenal atresia".

X-ray (Fig. 2): "After treatment of esophageal atresia and duodenal atresia".

X-ray (Fig. 3): "Cardiomegaly".

ECG (Fig. 4): "Sinus arrhythmia, heart rate of 171 - 150 beats per minute, the voltage was preserved, nomogram. Transition zone was displaced from V2 to V5. "P" - pulmonale. Changes in the repolarization phase of ventricular myocardium".

EchoCG (Fig. 5). Dilation of the right atrium. Hypertrophy of the right ventricle. Double outlet right ventricle (DORV), atrial septal defect (ASD) $11 \mathrm{~mm}$, ventricular septal defect (VSD) $9 \mathrm{~mm}$ (subaortic). Left ventricle ejection fraction was $50 \%$, average pressure in the pulmonary artery was $37 \mathrm{~mm} / \mathrm{Hg}$ (Il degree pulmonary hypertension).

Treatment of the child consisted of three stages.

I - operation: tracheoesophageal fistula ligation, transection and restoration with end to end anastamosis and duodeno-duodenostomy anastomosis.

II - treatment of heart failure: bed regimen; gavage; oxygen therapy; angiotensin converting enzyme inhibitors

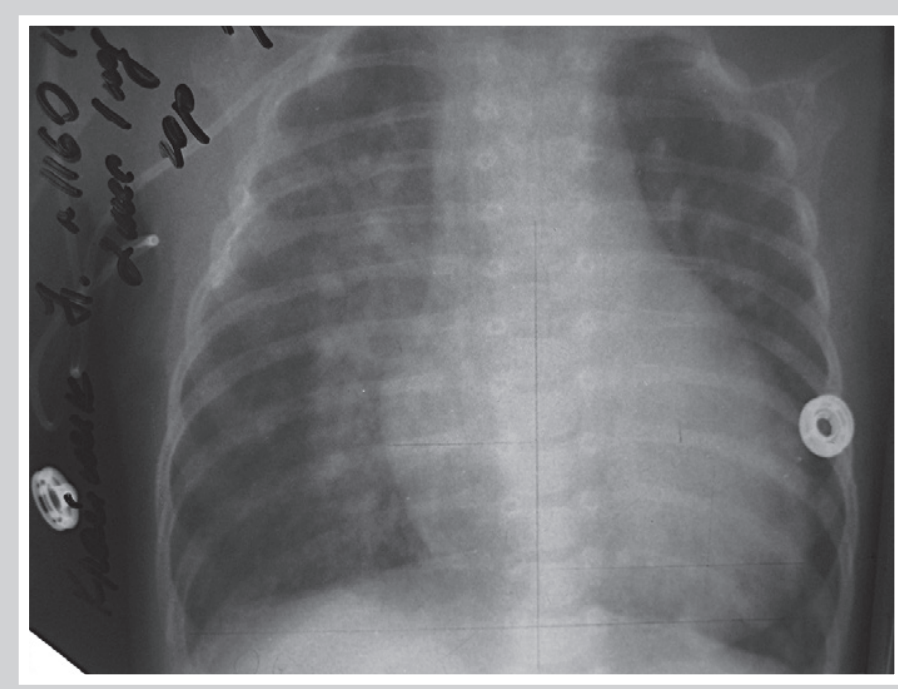

Fig. 3. X-ray "Cardiomegaly".

(ACEI) captopryl 0,5 mg/kg/day; diuretics: hypothiazide $1 \mathrm{mg} / \mathrm{kg} /$ day, furosemide $1 \mathrm{mg} / \mathrm{kg} /$ day; cardiotonic drugs: digoxin, dobutamine. The child had heart failure and malnutrition treatment. The girl was consultated by a cardiac surgeon repeatedly.

III - when the child's weight was 4-5 kg, she had surgery for congenital heart disease on 15.06.2015.

Medical care organization and provision for the child and the use of medicines based on medical indications were carried out in accordance with the requirements of the current legislation of Ukraine in the field of health protec- 


\section{Клинический случай}
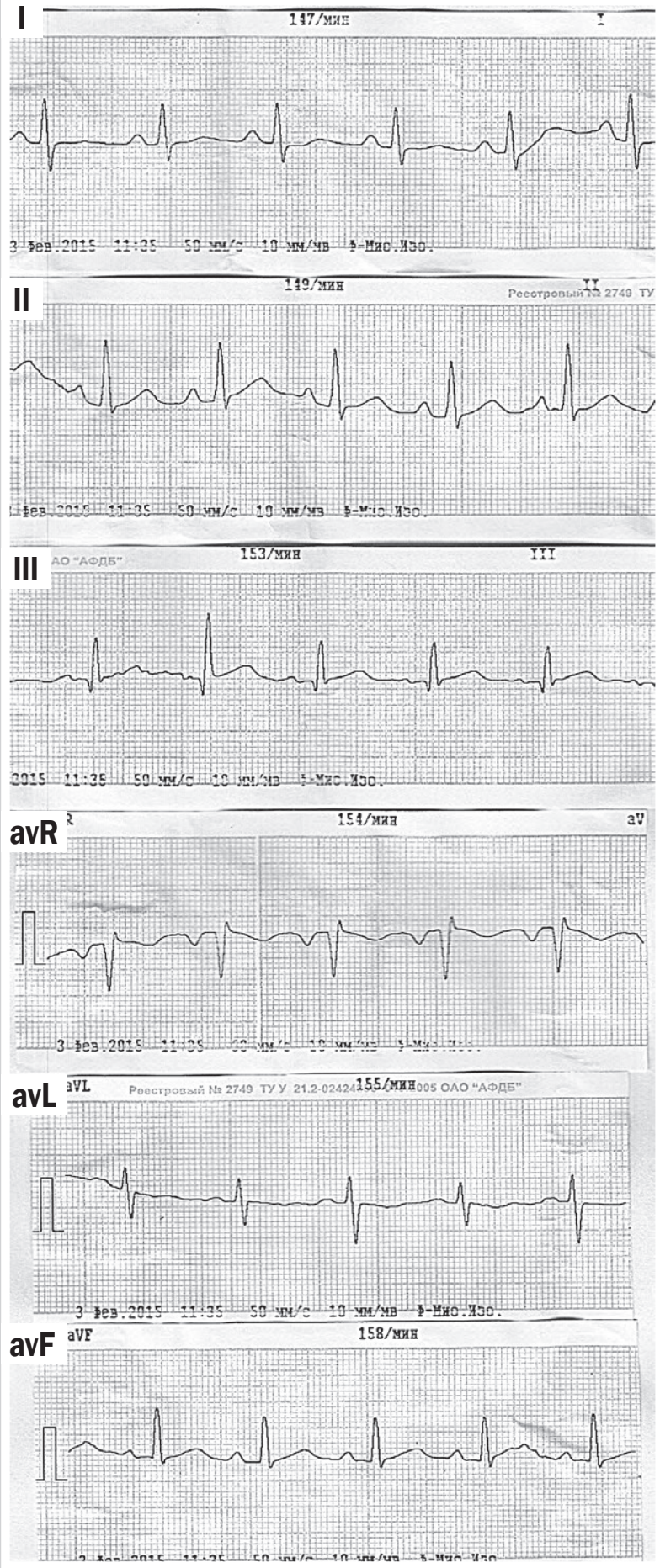
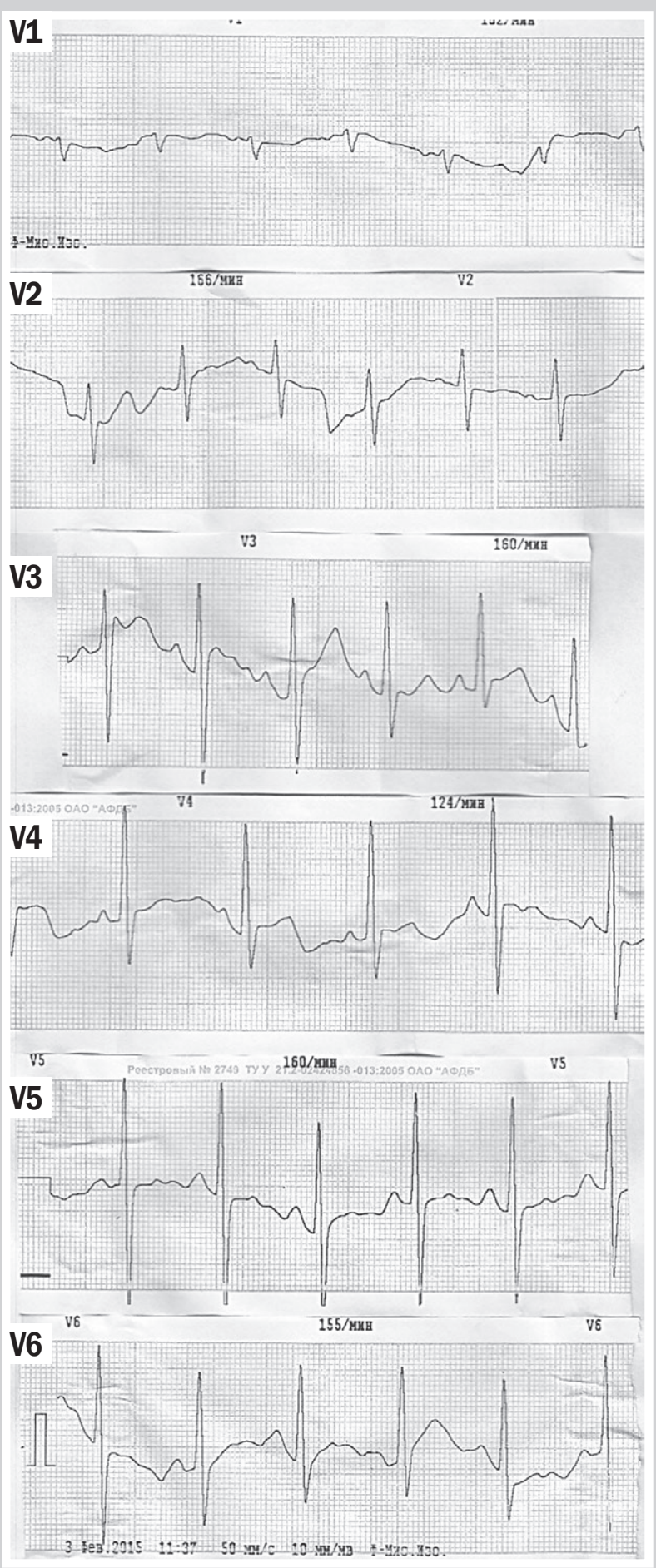

Fig. 4. ECG child with double outlet right ventricle, atrial septal defect, ventricular septal defect.

tion. Legal support of the medical staff of the hospital and the child's parents about the safe and effective treatment, the solution of various ethical and legal issues (in particular, the mechanism for providing voluntary informed consent of the child's parents for medical intervention) was conducted at the Department of Management and Pharmacy Economics, Medical and Pharmaceutical Commodity Research.

Currently, the child is on a dispensary observation by a cardiologist and gastroenterologist, girl's condition is as- sessed as satisfactory, there are no clinical signs of esophageal stenosis and heart failure; physical and psychomotor development corresponds to the age norm.

The given clinical case demonstrates the success of gastrointestinal tract (esophageal atresia, tracheoesophageal fistula, duodenal atresia) and cardiovascular system congenital anomalies (double outlet right ventricle, atrial septal defect, ventricular septal defect) surgical treatment. 


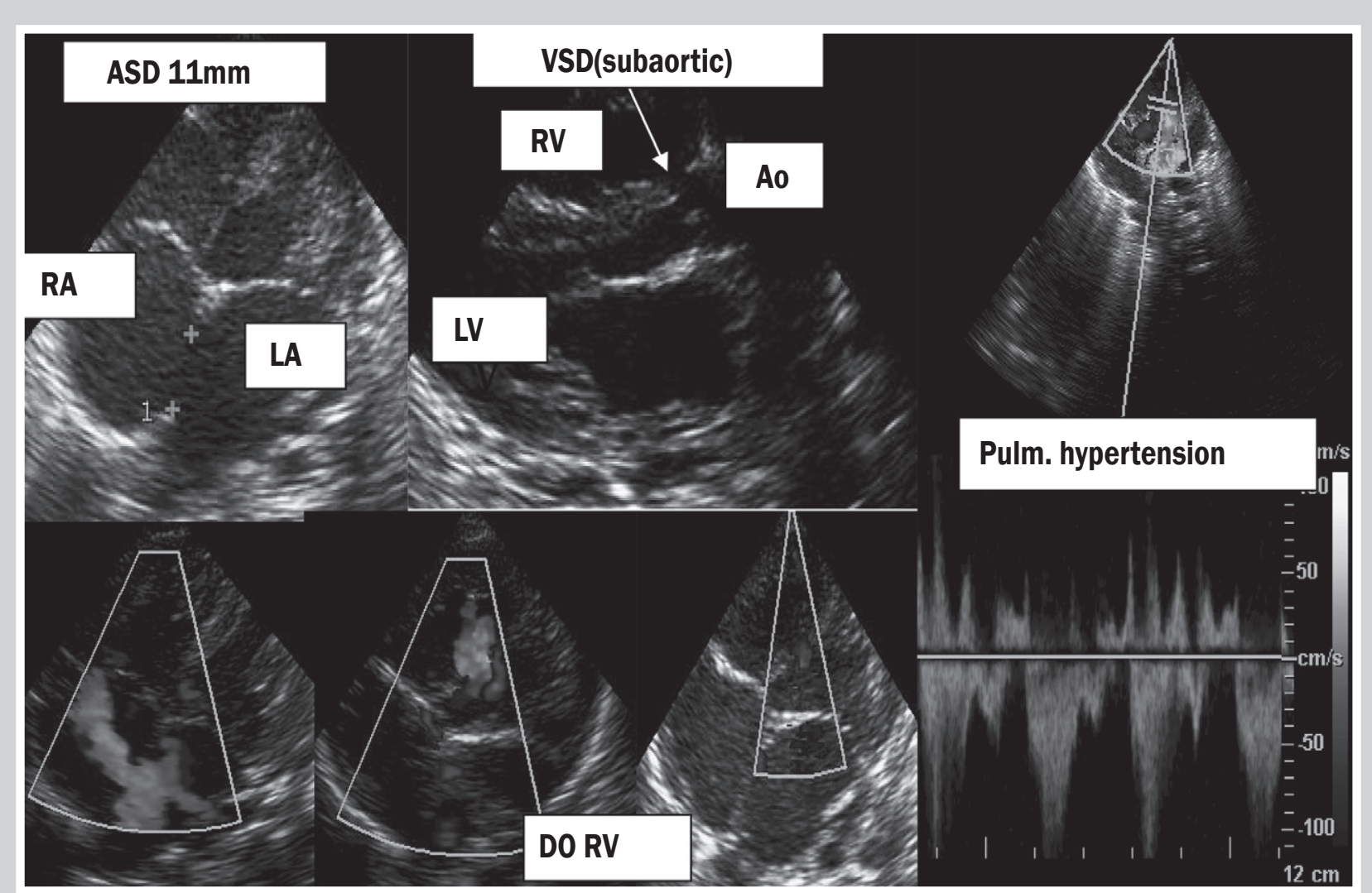

Fig. 5. Double outlet right ventricle (DORV), ASD,VSD (subaortic), pulmonary hypertension.

\section{Conclusions}

1. All pregnant women should undergo ultrasound and screening genetic examinations to exclude or diagnose congenital malformations in the fetus.

2. The success of therapy and surgical correction, the quality of child life depend on timely diagnosis, continuity and good teamwork of neonatologists, pediatric surgeons, cardiologists, pediatricians, diagnosticians.

\section{References}

[1] Tchaikovska, G. S., Gnateyko, A. Z., Dvorakevich, A. A., \& Stenik, R. V. (2014). Vnesok vrodzhenykh vad rozvytku travnoi systemy v strukturu letalnosti novonarodzhenykh ditei [Contribution of congenital malformations of the digestive system in the structure of mortality of newborns]. Neonatolohiia, khirurhiia ta perinatalna medytsyna, 4, 1(11), 57-60 [in Ukrainian].

[2] Martinucci, I., Bortoli, N., Giacchino, M., Bodini, G., Marabotto, E., Marchi, S., et al. (2014). Esophageal motility abnormalities in gastroesophageal reflux disease. World J. Gastrointest Pharmacol. Ther., 5(2), 86-96. doi: 10.4292/wjgpt.v5.i2.86.

[3] Avramenko, I. Yu. (2015). Analiz likuvannia ditei z mnozhynnymy vrodzhenymy vadamy rozvytku [Analysis of treatment of children with multiple congenital malformations]. Zhurnal klinichnykh ta eksperymentalnykh medychnykh doslidzhen, 3, 63-69. [in Ukrainian].

[4] Volosovets, O. P., Nedelska, S. M., Kryvopustov, S. P., Shumna, T. Ye., Solodova, I. V., Mazur, V. I. et al. (2008). Dytiacha kardiorevmatolohiia (okremi pytannia) [Pediatric cardiothorathology (individual issues)]. Zaporizhzhya: Orbita-Yug [in Ukrainian].

[5] Mahdich, Daliri Ghouchan Atigh, Hassan, Motaghi, Atieh, Eslahi, Zahra, Jafari, Sara, Shahidi, Mahdi, Keyvanlou, \& Mohammad Hassanzadeh Nazarabadi1 (2015). The frequency of congenital heart disorders among children issued from consanguineous marriages in khorasan province, northeast of iran. I. Biol. Biomed. J., 3, 98-102.

[6] Liu, D. X., Gilbert, M. H., Kempf, D. J., \& Didier, P. J. (2012). Double-outlet right ventricle and double septal defects in a rhesus macaque (macaca mulatta). J Vet Diagn Invest., 24, 188-191. doi: $10.1177 / 1040638711425951$

[7] Nakajima, Y. (2010). Second lineage of heart forming region provides new understanding of conotruncal heart defects. Congenit Anom (Kyoto), 50(1), 8-14. doi: 10.1111/j.1741-4520.2009.00267.x.

[8] Cherkasova, S. V., Mukhina, Yu. G., Ipatova, M. G., Kamaev, Yu. O., \& Bulgakova, N. T. (2015). Slozhnyj diagnosticheskij poisk. VACTERL-associaciya u novorozhdennogo rebenka [Complicated Diagnostic Process. VACTERL-Association in Newborn]. Trudnyj pacient, 1-2, 41-43 [in Russian].

[9] Tongsong, T., Chanprapaph, P., Sittiwangkul, R., \& Khunamornpong, S. (2007). Antenatal diagnosis of double outlet of right ventricle without extracardiac anomaly: a report of 4 cases. Journal of Clinical Ultrasound, 35(4), 221-225. doi: 10.1002/jcu.20297.

[10] Makarova, M. O. (2017). Peculiarities of surgical treatment of gastrointestinal tract combined congenital malformations in newborns. Zaporozhye medical journal, 19, 2(101), 172-174. doi: 10.14739/23101210.2017.2.95683.

\section{Information about authors:}

Shumna T. Ye., MD, PhD, DSc, Associate Professor, Department

of Faculty Pediatric, Zaporizhzhia State Medical University,

Ukraine.

Makarova M. 0., MD, PhD, Associate Professor, Department of Pediatric Surgery and Anesthesiology, Zaporizhzhia State Medical University, Ukraine.

Panchenko O. V., MD, Doctor, Diagnostics Department, Municipal Institution "City Multifield Children's Hospital No. 5", Zaporizhzhia, Ukraine.

\section{Відомості про авторів:}

Шумна Т. Є., А-р меА. наук, Аоцент каф. факультетської педіатрії, Запорізький державний меАичний університет, україна.

Макарова М. О., канд. меА. наук, Аоцент каф. Аитячої хірургії та анестезіології, Запорізький Аержавний медичний університет, Україна. 
Панченко О. В., мікар ультразвукової діагностики, відділення ультразвукової діагностики, КУ “Міська багатопрофільна дитяча мікарня № 5", м. Запоріжжя, Україна.

\section{Сведения об авторах:}

Шумная Т. Е., А-р меА. наук, Аоцент каф. факультетской педиатрии, Запорожский государственный меАицинский университет, Украина.

Макарова М. О., канА. меА. наук, Аоцент каф. Аетской хирургии и анестезиологии, Запорожский государственный медицинский университет, Украина.

Панченко А. В., врач ультразвуковой Аиагностики, отАеление ультразвуковой Аиагностики, КУ «Городская многопрофильная Аетская больница № 5", г. Запорожье, Украина.

Conflicts of Interest: authors have no conflict of interest to declare. Конфлікт інтересів: віАсутній.

Надійшла Ао редакції / Received: 13.10.2017

Після Аоопрацювання / Revised: 16.10.2017

Прийнято Ао Аруку / Accepted: 25.10.2017 